\title{
Hemochromatosis type 2
}

INSERM

\section{Source}

INSERM. (1999). Orphanet: an online rare disease and orphan drug data base.

Hemochromatosis type 2. ORPHA:79230

Hemochromatosis type 2 (juvenile) is the early-onset and most severe form of rare hereditary hemochromatosis $(\mathrm{HH}$; see this term), a group of diseases characterized by excessive tissue iron deposition of genetic origin. 